\title{
Reversed-Phase HPLC as a method for the identification of gadoid fish species
}

Carmen Piñeiro - Carmen G. Sotelo - Isabel Medina - José M. Gallardo - Ricardo I. Pérez-Martín

Instituto de Investigaciones Marinas, Eduardo Cabello 6, E-36208 Vigo, Spain

Abstract

A simple and rapid method to identify raw or frozen gadoid fish species is described. The methodology is based on the HPLC separation of water-soluble proteins and monitoring at $230 \mathrm{~nm}$. Chromatographic profiles were reproducible between individuals belonging to the same species; lower variations in the relative retention time than in peak area percentage were observed. Results obtained from an ANOVA test allowed the distinction of characteristic peaks. Profiles were independent of fish quality: fish refrigerated for 10 days showed the same HPLC protein profile as those that were fresh. The ability of the identification procedure was checked by analysis of a set of frozen commercial samples.

Key words Fish species - Gadoids - Identification - HPLC - Sarcoplasmic proteins

Introduction

Identification of fish species is involved in several quality control aspects of seafood products, such as control of origin, and is also needed for compliance with labelling regulations and fishing policies [1]. The problem of species identification has gained even more importance because of the wide range of species which may be subjected to processing in different countries, or the overexploitation of some valuable fish species, which has led to the trade of other species of less value [2].

The identification of unprocessed fish is carried out mainly by examination of external morphological characteristics. However, since muscle is the major part of the fish used in the manufacture of seafood products, such as fillets, steaks or minced fish, techniques based on biochemical analyses are needed for identification. 
Electrophoretic analyses of sarcoplasmic proteins have been employed in the identification of fish species since 1953 [3-7]; however, the analyses involve a lengthy run time followed by visualization and analysis step. In spite of this, currently the only four methods that are recognized by the AOAC as official methods for fish species inspection are based on electrophoretic techniques [7].

Although the identification of species relies on the analysis of sarcoplasmic proteins using electrophoretic techniques, it is possible to analyse these proteins using other protein analysis methods [8], such as HPLC. Ashoor and Knox [1] and Osman et al. [9] reported the application of HPLC methods to the analysis of muscle proteins with the aim of species identification. However, most fish species analysed in these works were phylogenetically unrelated and, as a consequence, their protein profiles were very different. The differentiation between related species might be more complex, since their protein profiles may be very similar [10]. These HPLC methods separate sarcoplasmic proteins with a reversed-phase technique, based on differences in protein hydrophobicity that are a consequence of the constituent amino acid.

Among the different fish families that are consumed by human, the gadoids are the most preferred and, as a consequence, their commercial value is often high. Frozen seafood products made from these species are very common and a high proportion of the fish is eventually sold in the processed state.

The aim of the present work was to propose an HPLC method suitable for species identification of gadoids based on the separation of their sarcoplasmic proteins by reversed-phase chromatography. The time needed for the analysis of proteins using this technique is usually quite short, and there is the possibility of full automation. Also, HPLC techniques, as opposed to polyacrylamide gel electrophoretic analysis, present the great advantage of using reagents that are less harmful than polyacryalmide. Finally, the analysis cost of HPLC techniques is lower compared with that of isoelectric focusing. All these considerations suggest the possibility of using an HPLC technique as a method for routine analysis of fish species. 
Fish species. Four gadoids species were obtained fresh from a local market: pollack (Pollachius pollachius), hake (Merluccius merluccius), cod (Gadus morhua) whiting (Merlangius merlangus); Alaska Pollack (Theragra chalcogramma) was obtained frozen from a local frozen foods industry. At least five individuals of each species were used in order to obtain the HPLC profiles. Fish were degutted, skinned and muscle portions were stored at $-70{ }^{\circ} \mathrm{C}$ until analysis. Commercial frozen fish were used in order to carry out a series of blind tests.

Protein extracts. Of minced white muscle, $10 \mathrm{~g}$ was homogenized for 2 min with $20 \mathrm{ml}$ of deionized water using an UltraTurrax homogenizer. The homogenate was centrifuged $\left(\mathrm{RCF}_{\mathrm{av}} 53,000_{\mathrm{g}}, 10 \mathrm{~min}, 4^{\circ} \mathrm{C}\right)$ and the supernatant obtained constituted the protein extract used in the HPLC analyses. The protein concentration in each extract was determined using the Coomassie Protein Assay (Pierce, Rockford, USA).

The protein concentration of the extracts was adjusted to $2 \mathrm{mg} / \mathrm{ml}$ by dilution with distilled water. The diluted extracts were filtered through a $0.45-\mu m$ Millipore HVLP013 filter, prior to loading onto the HPLC column. Bovine serum albumin (BSA, $50 \mu \mathrm{g})$ was added to each protein extract, as internal standard.

HPLC. Analyses were performed with a Beckman System Gold HPLC coupled with an on-line UV 167 detector (Beckman, Palo Alto, USA) set at $230 \mathrm{~nm}$. Water-soluble proteins were loaded into a Biorad HiPore RP 304 (250x46 mm) C4 column with a guard column (30x4.6 mm) (Biorad) using a 100- $\mu$ l loop. A linear gradient elution from $35 \%$ of solvent A ( $0.1 \%$ trifluoroacetic acid) to $90 \%$ of solvent B (100\% acetonitrile containing $0.1 \%$ trifluoroacetic acid) over 35 min was used. The flow rate was 1 $\mathrm{ml} / \mathrm{min}$.

Relative retention times (RRT) were calculated by dividing each peak retention time by the corresponding BSA retention time. Area of peaks were converted to percentage (AP) excluding in this calculation BSA area counts. 
Statistical analysis. RRT data were subjected to one-way ANOVA tests according to Sokal and Rohlf [11]. Comparisons of means after ANOVA tests were performed using a least squares difference (LSD) method.

Results

Figures 1-5 show the separation of water-soluble proteins for five gadoid species using RP-HPLC; the resulting profiles were different for each of the species studied. Table 1 shows for each species and peak AP and RRT values. The variability of both parameters was established by analysing different individual fish of the same species. These results revealed low standard deviations for the RRT in contrast to the relatively high values obtained for the AP.

These relatively high standard deviations found for AP might have been caused by differences in the amount of protein in the water-based muscle extracts. However, the water-soluble protein content in different individuals of the same species was not very variable (Table 2). Comparisons with another species, Alaska pollack, showed a lower water-soluble protein content which was probably due to the period of frozen storage prior to the analysis [12]. Since most of these water-soluble proteins are enzymes involved in metabolic processes, the amount of these proteins present in the muscle of fish species could be subjected to variability due to both environmental factors - such as temperature, depth or salinity of water habitat, or food availability - and endogenous factor - such as age, sex or biological condition [13]. However, the RRT of the peaks corresponding to the same species showed minor variations, making them more useful for identification purposes compared with the area determinations.

The identification of species by an HPLC method relies on the existence of specific peaks; in order to find significant differences between peaks, corresponding to different species, an ANOVA test was performed using as variables the data of the RRT of each peak.

The ANOVA tests were significant, as expected ( $F=1354,4 ; P<0.01)$, and comparisons of means were performed in order to look for specific peaks that are representative of each species (Table 3). A number of specific peaks for each species were singled out 
since, together, they permit rapid characterization. On this basis, the presence of a peak with an RRT of 1.18 indicates that the sample may be pollack or whiting; this ambiguity is resolved by the presence of peaks with RRT values of 1.27 or 1.30 , representative of Pollack and whiting, respectively. Alaska pollack is easily recognized by the peak labelled as $\mathrm{A}_{6}$, with an RRT of 1.98. Hake had three peaks, $\mathrm{H}_{4}, \mathrm{H}_{5}$ and $\mathrm{H}_{9}$, that are species specific, which makes the pattern of peaks for hake quite different from those for the other species. For the identification of cod, three peaks are necessary: $C_{1}$ allows differentiation between cod and whiting; $\mathrm{C}_{2}$ differentiates cod from hake and pollack; and $\mathrm{C}_{3}$, from Alaska pollack.

However, it is necessary to test whether these water-soluble protein profiles are maintained under different storage conditions. It is known that factors related to the conditions of capture of the fish, or to those after capture might have an influence on the sarcoplasmic fraction, mainly due to the existence of proteases acting during the postmortem period [14]. Another important factor is the postmortem storage temperature, because relatively high temperatures allow the activity of endogenous and bacterial enzymes. Freezing and frozen storage temperatures could also have some effect on sarcoplasmic proteins, for instance relatively high frozen storage temperatures provoke denaturation of sarcoplasmic proteins, which become unextractable [12].

In order to test for possible variations in the protein profiles due to storage on ice, the reproducibility of the HPLC procedure in terms of RRT was studied during an experiment of chill storage $\left(0^{\circ} \mathrm{C}\right)$. Table 4 shows the results obtained for hake kept on ice for 10 days. A broadening of the peaks took place as storage progressed, affecting slightly the resolution of the HPLC separation (Fig. 6). An important variation in the AP values with respect to those of fresh fish was also observed (Table 4). Both effects are probably a consequence of the denaturation of sarcoplasmic proteins. On one hand denaturation is reflected by a loss of solubility, which manifests as lower AP values, mostly for the main peaks such as $\mathrm{H}_{3}$. This could also mean a change in resolution, which might be as a direct consequence of protein structural change, the unfolding, which is also a manifestation of protein denaturation. Although these alterations were observed in the profile of hake preserved on ice for 10 days, the study of the RRT variability with storage time indicated that variation coefficients of this parameter were 
around 1\%, making the technique useful for identification purposes even in the case of poor-quality chilled fish.

In order to assess the efficiency of the proposed procedure, a blind test was carried out using fresh and frozen samples belonging to a wide group of samples labelled as white fish. Results are summarized in Table 5. Identification made on the basis of RRT was successful for all samples tested, showing the capability of the HPLC profiles to characterize gadoids. In some cases, samples 7-9a, specific profile was assigned by using only the major specific peaks because minor peaks were not present, probably due to the fact that the fish were kept frozen for a relatively long period of time.

The results presented here show that an HPLC technique is a powerful tool for the identification of phylogenetically related fish species. This methodology seems to be independent of any protein damage that occurs during fish storage at low temperatures, and at both chill and freezing temperatures, since no significant variations in the specific peak RRT values observed for fish stored or ice or stored frozen. The use of this HPLC technique is rapid and simple enough to be employed as routine analysis.

Acknowledgements

We are grateful to CICYT for financial support of Research Project ALI 95-0053 and Research Project CEE UP.3-783 (of DG XIV). Also we thank Helena Pazó for her assistance in the experimental work.

References

1. Ashoor SH, Knox MJ (1985) J Chromatogr 324: 199-202

2. Morrow JB (1992) In: Bligh EG (ed) Seafood science and technology. Fishing News Books, UK, pp 1-11

3. Connel JJ (1953) Biochem J 55: 378-388

4. Cowie W (1968) J Sci Food Agric 19: 226-229

5. Mackie IM (1969) J Assoc Publ Anal 7: 83-87

6. Lundstrom RC (1979) J Assoc Off Anal Chem 46: 1003-1005 
7. Helrich K (ed) (1990) Official methods of analysis, vol II, $15^{\text {th }}$ edn. AOAC, Arlington, pp 883-889

8. Sotelo CG, Piñeiro C, Gallardo JM, Pérez Martin RI (1993) Trends Food Sci 4: 395401

9. Osman MA, Ashoor SH, Marsh PC (1987) J Assoc Off Anal Chem 70: 618-625

10. Corzo J, Riol-Cimas JM, Meléndez-Hevia E (1984) Electrophoresis 5: 168-170

11. Sokal R, Rohlf F (1981) Biometry, 2nd edn. Freeman, San Francisco

12. Le Blanc EL, Le Blanc RJ (1989) J Food Sci 54: 827-833

13. Haard NF (1990) J Muscle Foods 1: 293-338

14. Hobbs G (1982) Changes in fish after catching. In: Aitkin A et al. (eds) Fish handling and processing. Her Majesty Station Office, Edinburgh, pp 20-27 
Table 1 RRT and AP with corresponding standard deviations for each peak for each species. ( $n$ Number of individuals analysed, $R R T$ relative retention time, $A P$ percentage area of the peak)

\begin{tabular}{|c|c|c|c|c|c|}
\hline Species & Parameter & & & & \\
\hline & PEAK & RRT & SD & AP & SD \\
\hline Whiting & & & & & \\
\hline & $\mathrm{W}_{1}$ & 1.18 & 0.01 & 10.06 & 1.14 \\
\hline & $\mathrm{W}_{2}$ & 1.30 & 0.01 & 12.10 & 0.95 \\
\hline & $\mathrm{W}_{3}$ & 1.37 & 0.01 & 14.06 & 1.60 \\
\hline & $\mathrm{W}_{4}$ & 1.46 & 0.01 & 5.47 & 1.32 \\
\hline & $\mathrm{W}_{5}$ & 1.58 & 0.01 & 32.79 & 1.58 \\
\hline & $\mathrm{W}_{6}$ & 1.78 & 0.01 & 2.61 & 0.32 \\
\hline & $\mathrm{W}_{7}$ & 1.93 & 0.03 & 14.91 & 1.02 \\
\hline & $\mathrm{W}_{8}$ & 2.18 & 0.03 & 3.79 & 0.69 \\
\hline & $\mathrm{W}_{9}$ & 2.27 & 0.02 & 3.79 & 1.02 \\
\hline Pollack & & & & & \\
\hline & $\mathrm{P}_{1}$ & 1.18 & 0.03 & 7.94 & 4.05 \\
\hline & $\mathrm{P}_{2}$ & 1.28 & 0.01 & 22.03 & 4.02 \\
\hline & $\mathrm{P}_{3}$ & 1.37 & 0.02 & 38.52 & 6.21 \\
\hline & $\mathrm{P}_{4}$ & 1.53 & 0.01 & 11.27 & 5.81 \\
\hline & $\mathrm{P}_{5}$ & 1.73 & 0.03 & 2.94 & 0.65 \\
\hline & $\mathrm{P}_{6}$ & 1.90 & 0.04 & 11.86 & 5.55 \\
\hline & $\mathrm{P}_{7}$ & 2.31 & 0.04 & 5.45 & 1.67 \\
\hline Alaska F & & & & & \\
\hline & $A_{1}$ & 1.14 & 0.01 & 10.65 & 1.98 \\
\hline & $\mathrm{A}_{2}$ & 1.30 & 0.01 & 37.29 & 1.88 \\
\hline & $A_{3}$ & 1.34 & 0.01 & 20.31 & 3.61 \\
\hline & $\mathrm{A}_{4}$ & 1.49 & 0.03 & 6.77 & 1.59 \\
\hline & $A_{5}$ & 1.53 & 0.01 & 7.68 & 1.52 \\
\hline & $\mathrm{A}_{6}$ & 1.98 & 0.04 & 17.29 & 1.75 \\
\hline $\operatorname{Cod}(n=$ & & & & & \\
\hline & $\mathrm{C}_{1}$ & 1.14 & 0.02 & 15.28 & 1.35 \\
\hline
\end{tabular}




\begin{tabular}{|l|l|l|l|l|l|}
\hline & $\mathrm{C}_{2}$ & 1.29 & 0.03 & 22.77 & 1.20 \\
\hline & $\mathrm{C}_{3}$ & 1.36 & 0.02 & 18.86 & 1.92 \\
\hline & $\mathrm{C}_{4}$ & 1.48 & 0.01 & 7.68 & 1.15 \\
\hline & $\mathrm{C}_{5}$ & 1.52 & 0.03 & 10.03 & 2.15 \\
\hline & $\mathrm{C}_{6}$ & 1.61 & 0.03 & 3.32 & 0.36 \\
\hline & $\mathrm{C}_{7}$ & 1.81 & 0.03 & 7.41 & 2.24 \\
\hline & $\mathrm{C}_{8}$ & 1.92 & 0.03 & 5.84 & 0.33 \\
\hline & $\mathrm{C}_{9}$ & 2.18 & 0.04 & 5.29 & 0.68 \\
\hline & $\mathrm{C}_{10}$ & 2.31 & 0.05 & 3.53 & 0.16 \\
\hline & & & & & \\
\hline & $\mathrm{H}_{1}$ & 1.14 & 0.01 & 14.75 & 1.36 \\
\hline & $\mathrm{H}_{2}$ & 1.25 & 0.01 & 12.24 & 1.14 \\
\hline & $\mathrm{H}_{3}$ & 1.33 & 0.01 & 12.40 & 1.01 \\
\hline & $\mathrm{H}_{4}$ & 1.41 & 0.02 & 18.83 & 1.16 \\
\hline & $\mathrm{H}_{5}$ & 1.55 & 0.01 & 15.89 & 2.73 \\
\hline & $\mathrm{H}_{6}$ & 1.66 & 0.02 & 3.36 & 0.37 \\
\hline & $\mathrm{H}_{7}$ & 1.81 & 0.03 & 2.61 & 0.21 \\
\hline & $\mathrm{H}_{8}$ & 1.87 & 0.02 & 4.34 & 1.00 \\
\hline & $\mathrm{H}_{9}$ & 2.09 & 0.06 & 4.66 & 0.33 \\
\hline & $\mathrm{H}_{10}$ & 2.21 & 0.06 & 10.91 & 2.11 \\
\hline & & & & \\
\hline & & & & \\
\hline & & & & &
\end{tabular}


Table 2 Protein concentration in the water extract

\begin{tabular}{|l|l|l|l|}
\hline Species & Protein concentration $(\mathrm{mg} / \mathrm{ml})$ & $n$ & SD \\
\hline Hake & 19.45 & 6 & 5.21 \\
\hline Cod & 11.87 & 5 & 2.80 \\
\hline Whiting & 19.02 & 7 & 4.27 \\
\hline Pollack & 10.56 & 5 & 1.63 \\
\hline Alaska Pollack & 5.75 & 6 & 0.80 \\
\hline
\end{tabular}

Table 3 Specific peaks for each species resulting from comparison of means by LSD. Key to peaks is as in Table 1

\begin{tabular}{|l|l|l|l|l|l|l|l|l|l|l|l|l|l|l|l|l|l|l|}
\hline Species & RRT & & & & & & & & & & & & & & & & & \\
\hline & 1.14 & 1.18 & 1.27 & 1.30 & 1.34 & 1.37 & 1.41 & 1.48 & 1.53 & 1.55 & 1.60 & 1.69 & 1.79 & 1.90 & 1.98 & 2.09 & 2.20 & 2.29 \\
\hline Pollack & & $\mathrm{P}_{1}$ & $\mathrm{P}_{2}$ & & & $\mathrm{P}_{3}$ & & & $\mathrm{P}_{4}$ & & & $\mathrm{P}_{5}$ & & $\mathrm{P}_{6}$ & & & & $\mathrm{P}_{7}$ \\
\hline $\begin{array}{l}\text { A. } \\
\text { Pollack }\end{array}$ & $\mathrm{A}_{1}$ & & & $\mathrm{~A}_{2}$ & $\mathrm{~A}_{3}$ & & & $\mathrm{~A}_{4}$ & $\mathrm{~A}_{5}$ & & & & & & $\mathrm{~A}_{6}$ & & & \\
\hline Hake & $\mathrm{H}_{1}$ & & $\mathrm{H}_{2}$ & & $\mathrm{H}_{3}$ & & $\mathrm{H}_{4}$ & & & $\mathrm{H}_{5}$ & & $\mathrm{H}_{6}$ & $\mathrm{H}_{7}$ & $\mathrm{H}_{8}$ & & $\mathrm{H}_{9}$ & & \\
\hline Cod & $\mathrm{C}_{1}$ & & & $\mathrm{C}_{2}$ & & $\mathrm{C}_{3}$ & & $\mathrm{C}_{4}$ & $\mathrm{C}_{5}$ & & $\mathrm{C}_{6}$ & & $\mathrm{C}_{7}$ & $\mathrm{C}_{8}$ & & & $\mathrm{C}_{9}$ & $\mathrm{C}_{10}$ \\
\hline Whiting & & $\mathrm{W}_{1}$ & & $\mathrm{~W}_{2}$ & & $\mathrm{~W}_{3}$ & & $\mathrm{~W}_{4}$ & & & $\mathrm{~W}_{5}$ & & $\mathrm{~W}_{6}$ & $\mathrm{~W}_{7}$ & & & $\mathrm{~W}_{8}$ & $\mathrm{~W}_{9}$ \\
\hline
\end{tabular}


Table 4 Variation of RRT and AP of peaks of hake water-soluble protein during chill storage. (CV Coefficient of variation)

\begin{tabular}{|l|l|l|l|l|l|l|l|l|l|l|l|l|}
\hline Peak & $0 \mathrm{~h}$ & & $48 \mathrm{~h}$ & & $72 \mathrm{~h}$ & & $168 \mathrm{~h}$ & & $240 \mathrm{~h}$ & & CV-RRT & CV-AP \\
\hline & RRT & AP & RRT & AP & RRT & AP & RRT & AP & RRT & AP & & \\
\hline $\mathrm{H}_{1}$ & 1.12 & 13.87 & 1.13 & 16.24 & 1.13 & 18.66 & 1.12 & 19.04 & 1.13 & 17.91 & 0.49 & 12.38 \\
\hline $\mathrm{H}_{2}$ & 1.24 & 11.67 & 1.24 & 12.42 & 1.25 & 13.06 & 1.23 & 13.19 & 1.25 & 12.96 & 0.67 & 4.95 \\
\hline $\mathrm{H}_{3}$ & 1.34 & 29.57 & 1.35 & 26.37 & 1.36 & 21.89 & 1.33 & 19.89 & 1.36 & 24.66 & 0.97 & 15.46 \\
\hline $\mathrm{H}_{4}$ & 1.40 & 6.80 & 1.43 & 7.12 & 1.43 & 8.63 & 1.42 & 9.45 & 1.47 & 7.98 & 1.78 & 13.58 \\
\hline $\mathrm{H}_{5}$ & 1.51 & 10.72 & 1.53 & 12.38 & 1.53 & 11.38 & 1.53 & 12.97 & 1.54 & 12.87 & 0.72 & 8.13 \\
\hline $\mathrm{H}_{6}$ & 1.64 & 2.79 & 1.66 & 3.19 & 1.66 & 3.37 & 1.64 & 3.71 & 1.68 & 3.22 & 1.01 & 10.21 \\
\hline $\mathrm{H}_{7}$ & 1.77 & 2.36 & 1.79 & 2.71 & 1.79 & 3.02 & 1.76 & 3.73 & 1.80 & 3.31 & 0.92 & 17.48 \\
\hline $\mathrm{H}_{8}$ & 1.88 & 6.04 & 1.89 & 4.29 & 1.90 & 3.87 & 1.87 & 3.67 & 1.90 & 4.20 & 0.69 & 21.36 \\
\hline $\mathrm{H}_{9}$ & 2.04 & 5.72 & 2.07 & 4.95 & 2.05 & 4.44 & 2.03 & 3.60 & 2.08 & 3.62 & 1.01 & 20.26 \\
\hline $\mathrm{H}_{10}$ & 2.20 & 10.46 & 2.21 & 10.33 & 2.22 & 11.67 & 2.20 & 10.74 & 2.23 & 9.25 & 0.59 & 8.28 \\
\hline
\end{tabular}


Table 5 Water-soluble protein RRT values from commercial frozen fish samples. Species assignment using RRT values obtained in this study

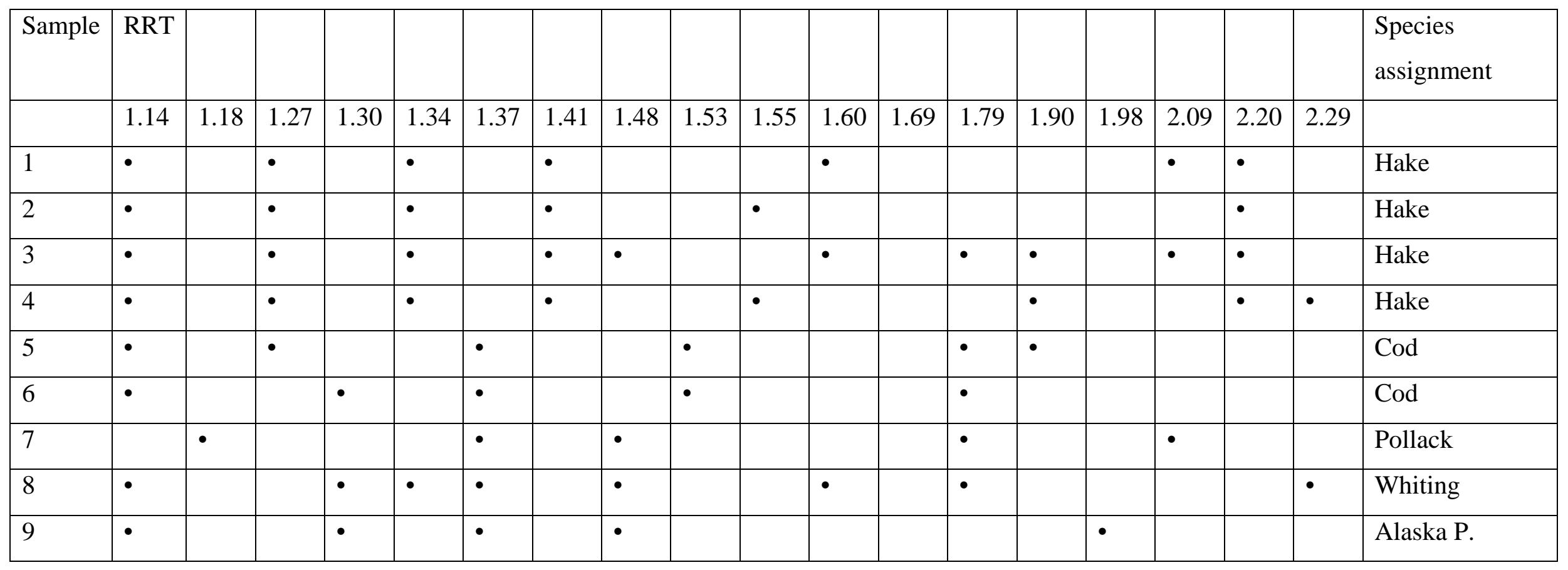

Fig. 1 HPLC chromatogram of whiting sarcoplasmic proteins. Peaks are labelled as in Table 1

Fig. 2 HPLC chromatogram of pollack sarcoplasmic proteins. Peaks are labelled as in Table 1 
Fig. 3 HPLC chromatogram of Alaska pollack sarcoplasmic proteins. Peaks are labelled as in Table 1

Fig. 4 HPLC chromatogram of cod sarcoplasmic proteins. Peaks are labelled as in Table 1

Fig. 5 HPLC chromatogram of hake sarcoplasmic proteins. Peaks are labelled as in Table 1

Fig. 6 HPLC chromatograms of sarcoplasmic proteins from hake maintained at $0{ }_{i} \mathrm{C}$ for 0 and 72 h. Peaks are labelled as in Table 1 